\title{
Hydrodynamic studies in an airlift reactor with an enlarged degassing zone
}

\author{
C. Freitas, J.A. Teixeira
}

Abstract The hydrodynamic behaviour of a 601 threephase airlift bioreactor, of the concentric draught tube type, with an enlarged degassing zone has been studied. Ca-alginate beads were used as the solid phase. Airflow rate (from 1.9 to $90.2 \mathrm{l} / \mathrm{min}$ ), solids loading ( $0 \%$ to $40 \%$ $(\mathrm{v} / \mathrm{v}))$ and solids density $\left(1016\right.$ and $1038 \mathrm{~kg} / \mathrm{m}^{3}$ ) were manipulated and their influence on solids and gas holdup, circulation and mixing times and in the interstitial liquid velocity was determined. Riser and downcomer solids holdup was found to decrease with the increase of airflow rate and to increase with solids loading and density. On the contrary, gas holdup in the riser and in the downcomer increased with airflow rate and decreased with solids loading and density. By increasing airflow rate, a decrease in circulation time was observed while the effects of solids loading and density were negligible. Mixing time decreased with airflow rate, increased with solids density, in the studied range, and presented a maximum for solids loading of approximately $20 \%(\mathrm{v} / \mathrm{v})$.

\section{List of symbols}

$A_{d} \quad \mathrm{~m}$

$A_{r} \quad \mathrm{~m}$

d $\mathrm{m}$

$\mathrm{H}_{1}-\mathrm{H}_{2} \mathrm{cmH}_{2} \mathrm{O}$

$t_{c} \quad \mathrm{~s}$

$t_{m} \quad s$

$u_{l} \quad \mathrm{~m} / \mathrm{s}$

$u_{l d} \quad \mathrm{~m} / \mathrm{s}$

$u_{l r} \quad \mathrm{~m} / \mathrm{s}$ downcomer cross-section area riser cross-section area vertical distance between two points in the riser and in the downcomer pressure difference between two points of the riser and of the downcomer circulation time mixing time interstitial liquid velocity downcomer interstitial liquid velocity riser interstitial liquid velocity

Received: 21 April 1997

C. Freitas, J.A. Teixeira

I.B.Q.F. (Instituto de Biotecnologia e Química Fina), Departamento de Engenharia Biológica,

Universidade do Minho, Campus de Gualtar,

4709 Braga codex, Portugal

Correspondence to: J.A. Teixeira

This work was supported by J.N.I.C.T (Junta Nacional de Investigação Científica e Tecnológica) under Grant GGP XXI/BD/ $2937 / 96$.

$\begin{array}{ll}v_{g r} & \mathrm{~m} / \mathrm{s} \\ V_{s} & 1 \\ & \\ V_{T} & 1 \\ \Delta t & \mathrm{~s}\end{array}$

riser superficial gas velocity solids volume measured in each sample sample total volume time required by the tracer to travel along the riser and the downcomer gas holdup in the downcomer gas holdup in section $i$ gas holdup in the riser solids holdup in the downcomer solids holdup in section $i$ solids holdup in the riser $\mathrm{kg} / \mathrm{m}^{3} \quad$ liquid density $\mathrm{kg} / \mathrm{m}^{3} \quad$ solids density

1

\section{Introduction}

Airlift reactors are reaction vessels divided into two main sections - the riser, where the gas is usually injected, and the downcomer. As a result of the different gas holdup in the riser and in the downcomer, the bulk density of the fluid in these zones is different and liquid circulation is induced. When there is a good gas-liquid separation in the top section of the bioreactor, gas holdup in the downcomer is negligible and the driving force for liquid circulation is maximal. While, for well designed external-loop airlift reactors, the top connection between the riser and the downcomer can be an effective gas-liquid separator, the top section of internal-loop airlift reactors needs to be specially designed for a complete gas-liquid separation. Most of the configurations used [1] are based on the principle of reducing the liquid velocity in the entrance of the downcomer to values below bubbles' rising velocity, to avoid their entrance into the downcomer. This can be achieved by increasing the cross-section area of the downcomer in the top of the reactor. Only a few studies were made with internal-loop airlift reactors having a significantly enlarged gas-liquid separator [2-7].

Airlift reactors have been raising an increasing interest due to their advantages, when compared to other reactors. Nevertheless, their industrial application still remains limited because hydrodynamic studies of the airlift reactors have been done, in most of the cases, only with gas-liquid systems. Since fermentation broths are gas-liquid-solid systems, the characterisation of the effect of solids on the hydrodynamics and on the gas-liquid mass transfer properties is receiving increasing interest and has been subject of some studies [7-17]. The importance of the 
solid phase becomes particularly relevant in cases when micro-organisms are immobilised in solid supports or flocculated as is the case of high cell density systems. However, most of the studies have been done with solids having densities different from those that occur in fermentation processes and the effect of biomass density variation during the whole process usually is not considered.

The behaviour of a bioreactor is determined not only by the reactor geometry but also by its hydrodynamic properties [18]. The analysis and description of the behaviour of an airlift reactor involves the study of parameters such as gas and solids holdup, mixing and liquid velocity. It is necessary to get information about the interaction between these parameters and the operation and the design variables, in order to make a correct design of the airlift bioreactor.

The purpose of this study was to investigate the influence of the solids loading (from $0 \%$ to $40 \%(\mathrm{v} / \mathrm{v})$ ), the density of the solid-phase $\left(1016\right.$ and $\left.1038 \mathrm{~kg} / \mathrm{m}^{3}\right)$ and the airflow rate $(1.9,5.5,9.1,13.6,30.3,58.8,90.21 / \mathrm{min})$ on gas and solids holdup, on mixing and circulation times and on liquid velocity, in a $60 \mathrm{l}$ concentric draught tube airlift bioreactor with an enlarged degassing zone.

\section{2}

\section{Materials and methods}

\section{1}

\section{The reactor}

A 601 airlift reactor of the concentric draught tube type, with an enlarged degassing zone, is used (Fig. 1). It is made of plexiglas with a thickness of $8 \mathrm{~mm}$. The total height of the reactor is $1.986 \mathrm{~m}$ and the fluid level is $0.530 \mathrm{~m}$ above the top of the draught tube. The height and the diameter of the downcomer are $1.190 \mathrm{~m}$ and $0.142 \mathrm{~m}$, respectively. The draught tube height and diameter are, respectively, $1.190 \mathrm{~m}$ and $0.062 \mathrm{~m}$ and its bottom edge is $0.086 \mathrm{~m}$ above the bottom of the reactor.

The top section is of the cylindrical conical type. The conical section forms a $51^{\circ}$ angle with the main body of the reactor and the height and diameter of the cylindrical part are, respectively, $0.350 \mathrm{~m}$ and $0.442 \mathrm{~m}$.

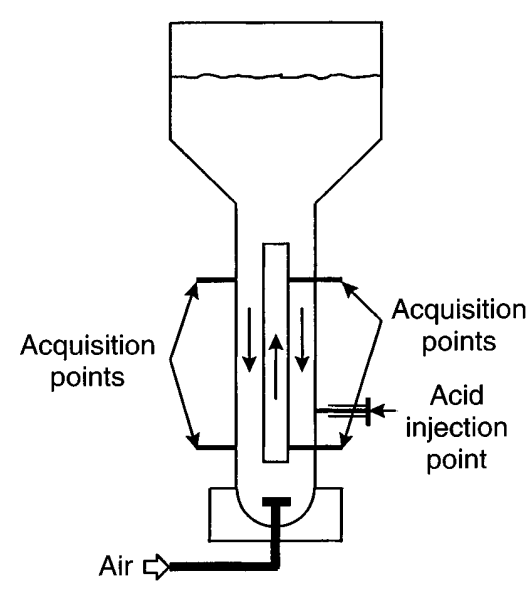

Fig. 1. Schematic diagram of the airlift reactor
A $0.030 \mathrm{~m}$ circular distribution plate, with 30 holes of $1 \mathrm{~mm}$ each, is used to inject air. It is placed $0.061 \mathrm{~m}$ below the bottom of the draught tube.

\section{2}

The solid-phase

Ca-alginate beads were used as solid-phase and were prepared according to the procedure described by Vicente and Teixeira [7]. Ca-alginate beads with two different densities were used. The mean diameter and density of the "low density beads" (LD) were $2.131 \pm 0.102 \mathrm{~mm}$ and $1016 \pm 1 \mathrm{~kg} / \mathrm{m}^{3}$, respectively, and the values for the "high density beads" (HD) were $2.151 \pm 0.125 \mathrm{~mm}$ and $1038 \pm 1 \mathrm{~kg} / \mathrm{m}^{3}$.

\section{3}

\section{Superficial gas velocity}

The superficial gas velocity $\left(v_{s g}\right)$ was calculated as the ratio between the air volumetric flow rate and the riser crosssection area.

\section{4}

\section{Solids holdup determination}

Solids holdup was measured at the top of the riser and of the downcomer, by sampling the gas-liquid-solid slurry. The sampler is a $60 \mathrm{ml}\left(V_{T}\right)$ cylinder with two valves at the top and at the bottom. When it was introduced into the reactor, the valves were open in the flow direction and, for sample collection, they were closed simultaneously. In each sample, solids volume $\left(V_{s}\right)$ was measured. With this value, solids holdup in riser and in downcomer $\left(\varepsilon_{s i}\right)$ was calculated:

$\varepsilon_{s i}=\frac{V_{s}}{V_{T}}$.

For each set of experimental conditions, three samples were taken.

\section{5}

\section{Gas holdup determination}

Gas holdup was determined for the riser $\left(\varepsilon_{g r}\right)$ and the downcomer $\left(\varepsilon_{g d}\right)$ by measuring the pressure difference between the top and the bottom of both the riser and the downcomer, with a differential pressure transducer connected to a data acquisition system, linked to a personal computer. In each section, the distance between the two pressure acquisition points is $d=1.09 \mathrm{~m}$ (see Fig. 1). Two pressure transducers - P3061-2WD and P3061-5WD, LCSP Shaevitz ${ }^{\mathrm{TM}}$ Pressure Sensors - for different working ranges (0-5 and $\left.0-13 \mathrm{cmH}_{2} \mathrm{O}\right)$ were used. For each set of experimental conditions, different pressure differences $\left(H_{1}-\mathrm{H}_{2}\right)$ in the riser and in the downcomer were measured three times, during $300 \mathrm{~s}$ each. The mean of the registered values was used for the calculation of gas holdup, for each section (i) of the reactor, by the equation:

$\varepsilon_{g i}=\frac{\left(H_{1}-H_{2}\right)_{i}}{d}-\frac{\rho_{l}-\rho_{s}}{\rho_{l}} \times \varepsilon_{s i}$. 


\section{6}

\section{Liquid phase characterisation}

Liquid phase circulation and mixing times and liquid velocity were determined by the $\mathrm{pH}$ pulse technique. Four $\mathrm{pH}$ sensors were placed in the top and in the bottom of the riser and of the downcomer, $0.136 \mathrm{~m}$ and $1.226 \mathrm{~m}$ above the bottom of the reactor, respectively (see Fig. 1). The signals of all $\mathrm{pH}$ sensors were transmitted to a computer by a data acquisition system (PCL-812PG Enhanced MultiLab Card, Advantech Co, Ltd). For each set of experimental conditions, the $\mathrm{pH}$ was first increased to a value around 10 by adding, at the top of the reactor, a sodium hydroxide solution $\left(10 \mathrm{~mol} / \mathrm{dm}^{3}\right)$. After stabilisation of the $\mathrm{pH}$ value, a pulse of $2.5 \mathrm{ml}$ sulphuric acid $\left(4.5 \mathrm{~mol} / \mathrm{dm}^{3}\right)$ was injected into the downcomer, $0.236 \mathrm{~m}$ above the bottom of the reactor, at time zero. The data acquisition was stopped once a constant $\mathrm{pH}$ value was achieved. Three replicates were made for each set of experimental conditions and, at the end of each experiment, the reactor was emptied and the alginate beads were washed, in order to minimise their turgescence caused by extreme $\mathrm{pH}$ conditions.

\subsection{1}

\section{Mixing and circulation times}

Mixing time $\left(t_{m}\right)$ was determined as the time required for the variation of the $\mathrm{pH}$ value to be within $5 \%$ of the final equilibrium value.

The circulation time $\left(t_{c}\right)$ was computed by averaging the time spans between maximum consecutive $\mathrm{pH}$ peaks in the $\mathrm{pH}$ response curve.

Mixing and circulation times were obtained independently for each of the four electrodes. Their final values, for each set of experimental conditions, are the average between the values registered by the four electrodes in the three replicates made.

\subsection{2}

\section{Interstitial liquid velocity}

The downcomer liquid velocity $\left(u_{l d}\right)$ was calculated directly from the peaks of the signals obtained by the two electrodes located in the downcomer, by knowing the time $(\Delta t)$ required by the tracer to travel from one to the other (distance $d$ of $1.09 \mathrm{~m}$ ):

$u_{l d}=\frac{d}{\Delta t\left(1-\varepsilon_{g d}-\varepsilon_{s d}\right)}$.

As turbulence and backmixing were more intense in the riser than in the downcomer, the interstitial liquid velocity in the riser $\left(u_{l r}\right)$ was calculated:

$u_{l r}=u_{l d} \times \frac{A_{d}}{A_{r}} \times \frac{\left(1-\varepsilon_{g d}-\varepsilon_{s d}\right)}{\left(1-\varepsilon_{g r}-\varepsilon_{s r}\right)}$

\section{Results and discussion}

\section{1}

\section{Solids holdup}

The effect of airflow rate on solids holdup in the riser $\left(\varepsilon_{s r}\right)$ and in the downcomer $\left(\varepsilon_{s d}\right)$ is shown in Fig. 2. No significant influence of the airflow rate is observed on either riser and downcomer solids holdup. Only when solids loading is high and for low riser superficial gas velocity $\left(v_{g r}\right)$, a pronounced decrease occurs. In these cases, as solids are more dense then water they do not rise so easily to the degassing zone, accumulating at the bottom of the reactor.
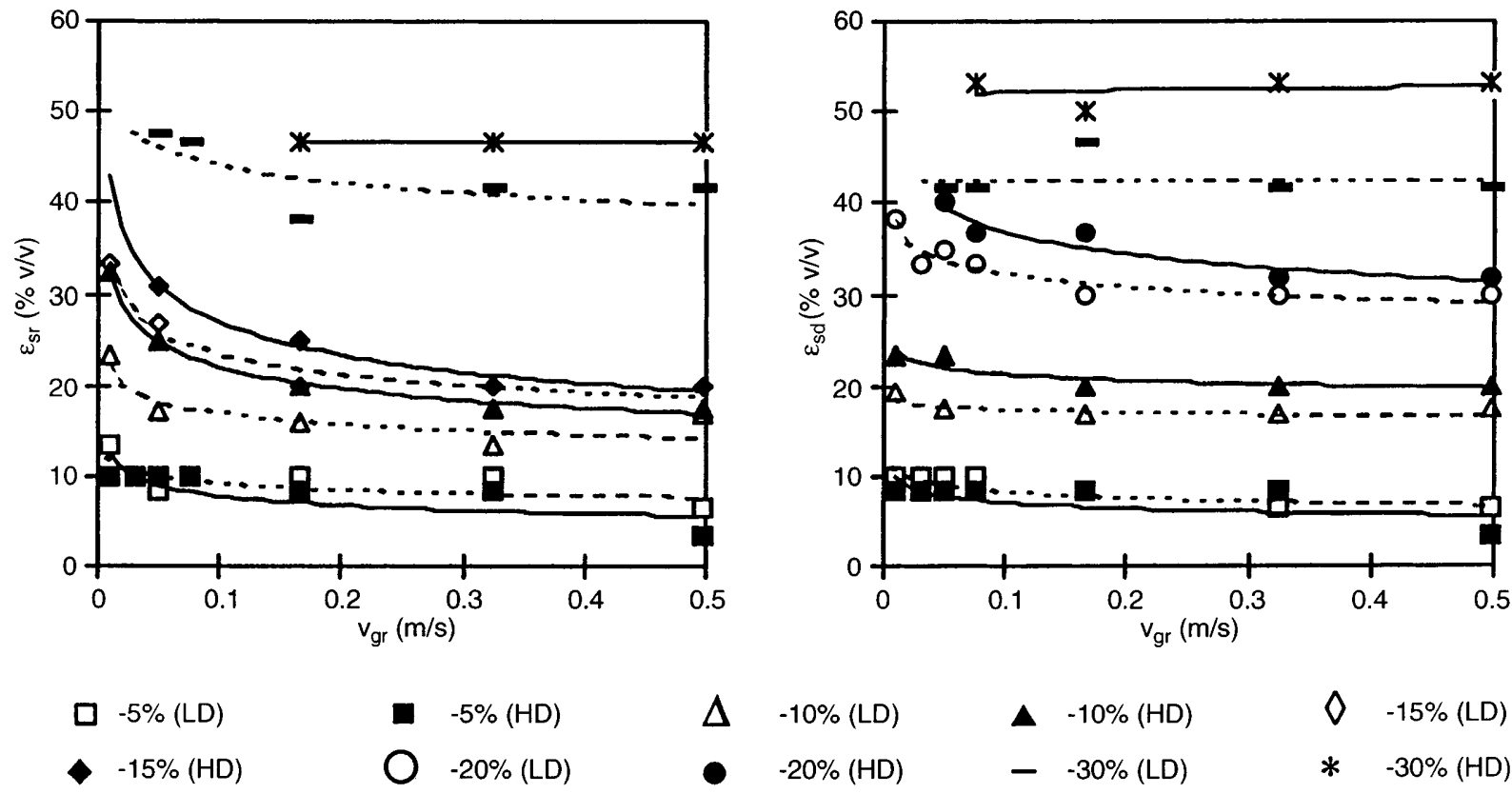

$$
\begin{aligned}
& -5 \%(H D) \\
& -20 \%(L D)
\end{aligned}
$$

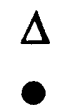

$-10 \%(\mathrm{LD})$
$-20 \%(\mathrm{HD})$

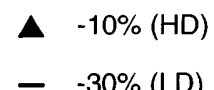

$0-15 \%$ (LD)

$-20 \%(\mathrm{HD}) \quad-30 \%(\mathrm{LD})$

* $-30 \%(\mathrm{HD})$

Fig. 2. Riser and downcomer solids holdup versus riser superficial gas velocity, for different solids loading and for low and high density beads 

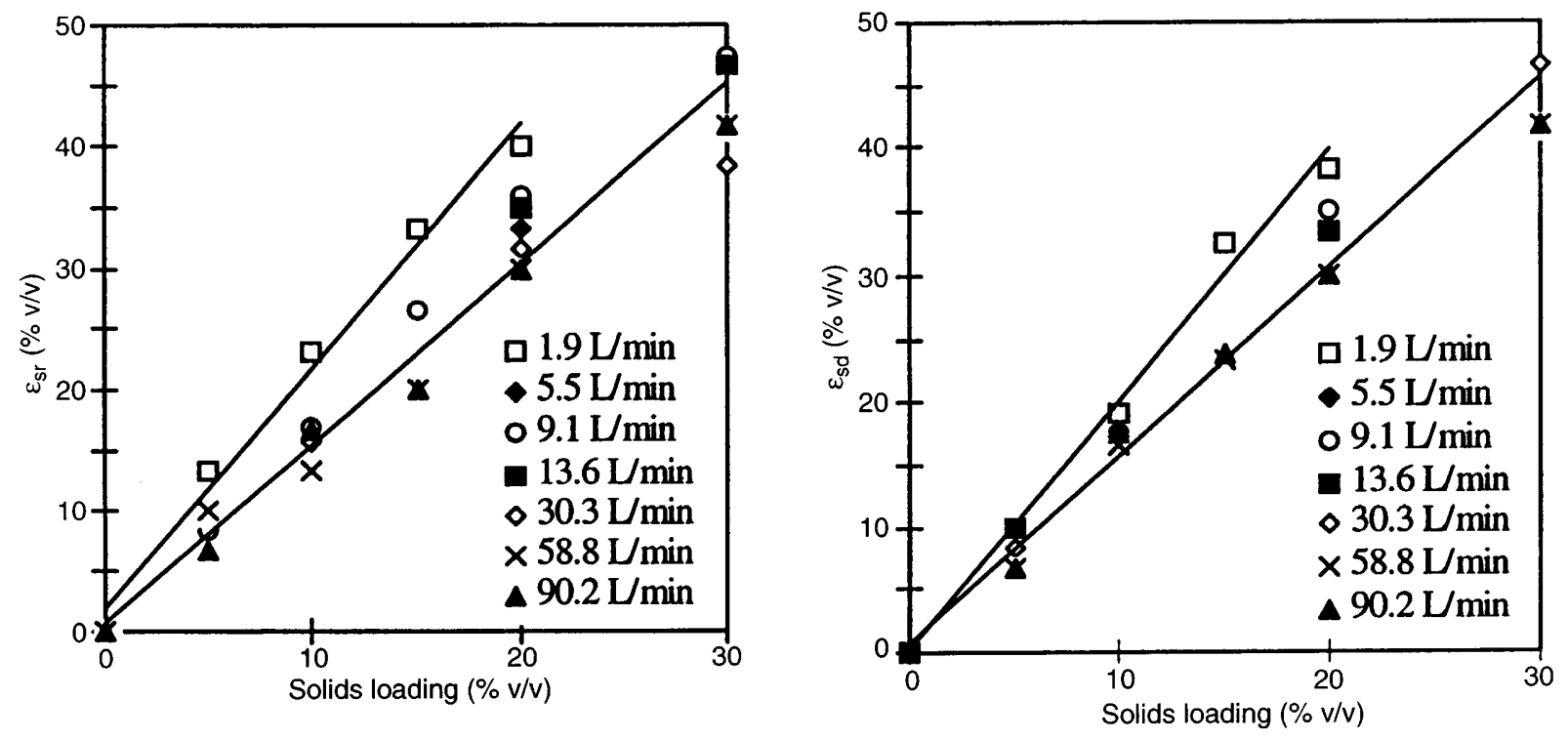

Fig. 3. Riser and downcomer solids holdup versus solids loading, for different airflow rates and for the low density beads

Similar values are obtained for riser and downcomer solids holdup indicating an uniform solids distribution between those two sections.

The increase in solids density leads to an increase of riser and downcomer solids holdup (Fig. 2). For the high density beads, the larger difference between solids and liquid densities prevents them from rising so easily to the degassing zone, increasing their residence time into the riser and the downcomer. For 5\% of solids, solids density has no influence on riser and downcomer solids holdup because, as solids volume is low, no significant difference is observed in the properties of the solid phase.

Results shown in Fig. 3 indicate a linear relationship between solids holdup in the riser and in the downcomer and solids loading. This linear relationship is the same for all airflow rates with the exception of $1.9 \mathrm{l} / \mathrm{min}$. This effect may be explained by the fact that the drag force obtained at this airflow rate induces a smaller velocity for solids transport than at higher airflow rates. This suggests, as indicated by Vicente et al. [7], that there is a minimal velocity to ensure solid phase circulation.

\section{2}

Gas holdup

Riser and downcomer gas holdup increases with the increase of airflow rate as shown in Fig. 4. It is seen that the increase of the riser gas holdup is higher for lower airflow rates, presenting small changes for riser superficial gas velocity higher than $0.32 \mathrm{~m} / \mathrm{s}$. This can be explained by a change in flux regime. Thus, for low airflow rates, the increase of riser superficial gas velocity leads to an increase of the amount of gas into the riser, that is, to an
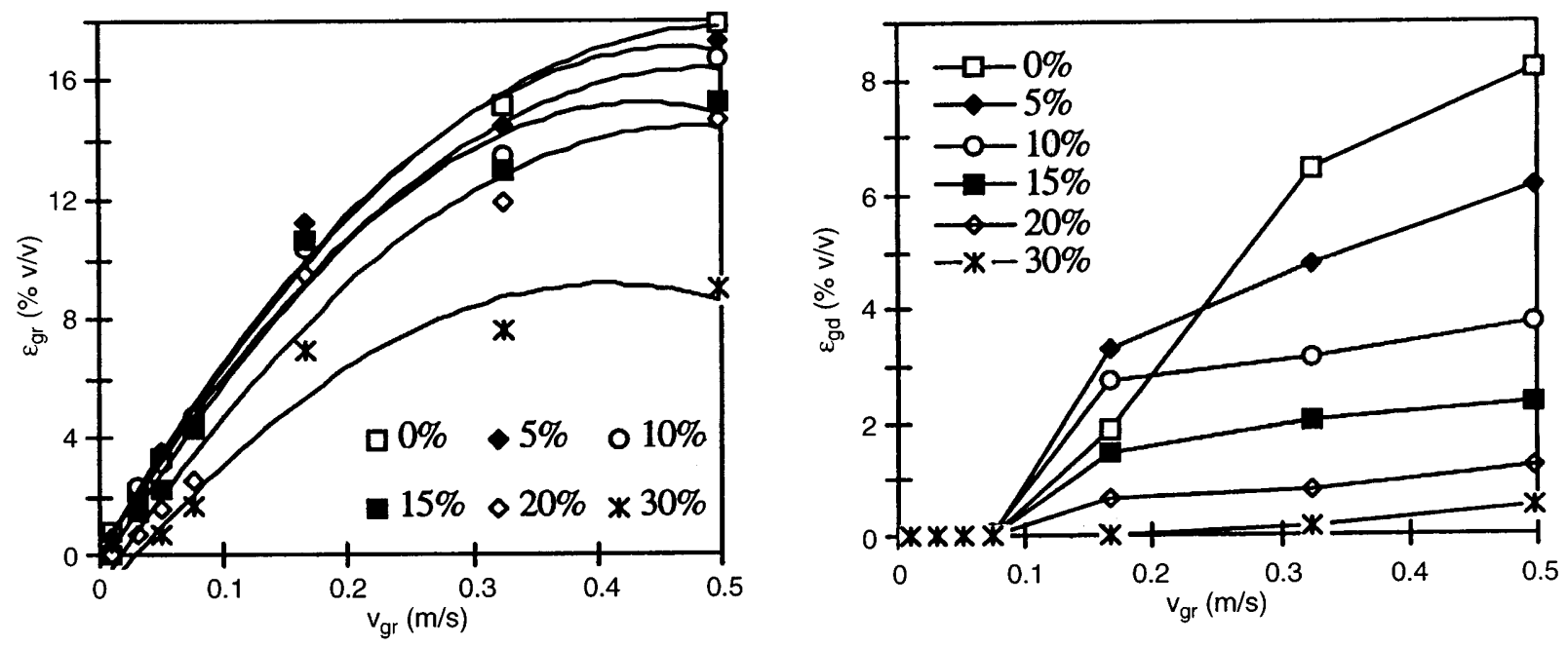

Fig. 4. Riser and downcomer gas holdup versus riser superficial gas velocity, for different solids loading and for the low density beads 


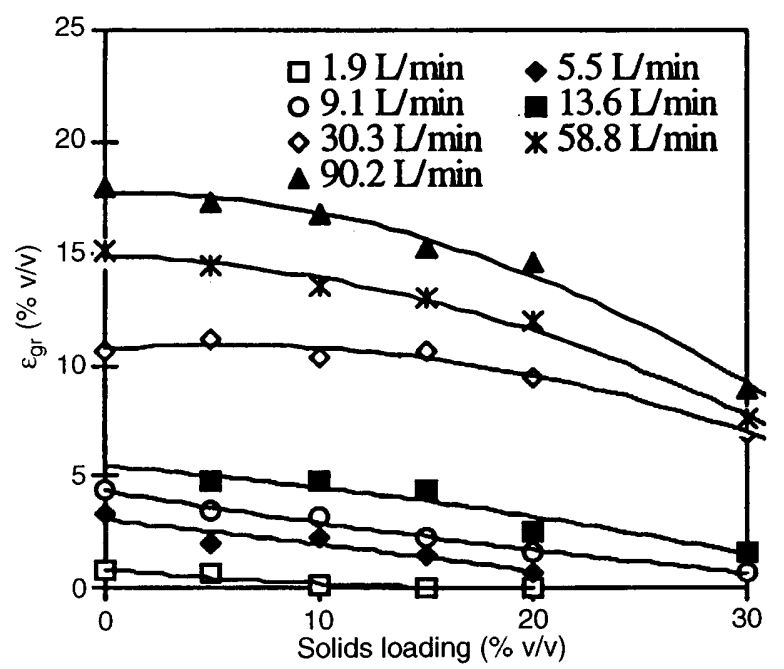

Fig. 5. Riser and downcomer gas holdup versus solids loading, for different airflow rates and for the low density beads

increase of the riser gas holdup. For high airflow rates, there is more contact between gas bubbles and bubble coalescence increases, giving rise to the formation of bigger air bubbles with higher rising velocities. The increase of airflow rate in this regime leads to an increase of the amount of those coalescent bubbles and to the decrease of the residence time of the gas phase, counterbalancing partially the enhancement of the amount of air that enters the reactor.

Riser gas holdup $\left(\varepsilon_{g r}\right)$ was correlated to the riser superficial gas velocity $\left(v_{g r}\right)$, for all solids loading and densities studied, in the form:

$\varepsilon_{g r}=\mathrm{a} v_{g r}^{2}+\mathrm{b} v_{g r}+\mathrm{c}$.

Downcomer gas holdup $\left(\varepsilon_{g d}\right)$ increases with airflow rate for values above $13.6 \mathrm{l} / \mathrm{min}$. For airflow rates below this value, air does not enter the downcomer and the gas holdup is zero, meaning that rising bubbles velocity is higher than the descending liquid velocity.

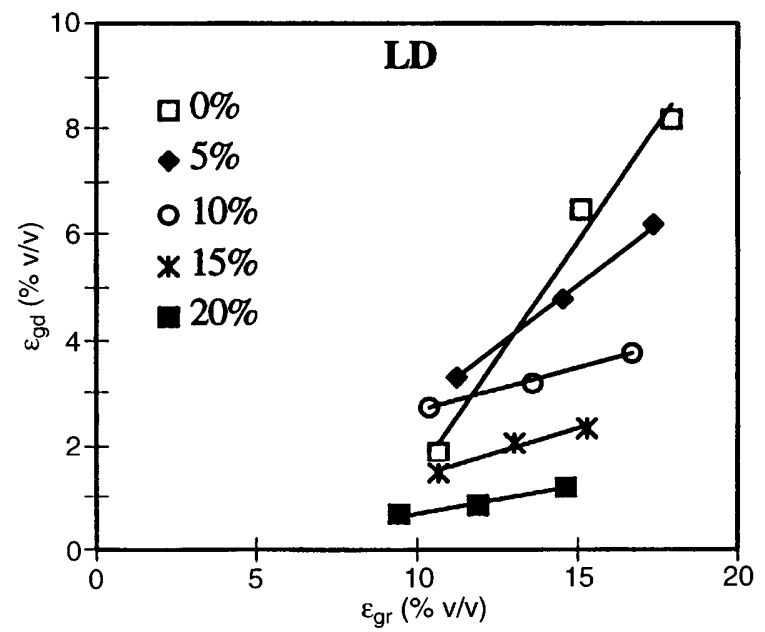

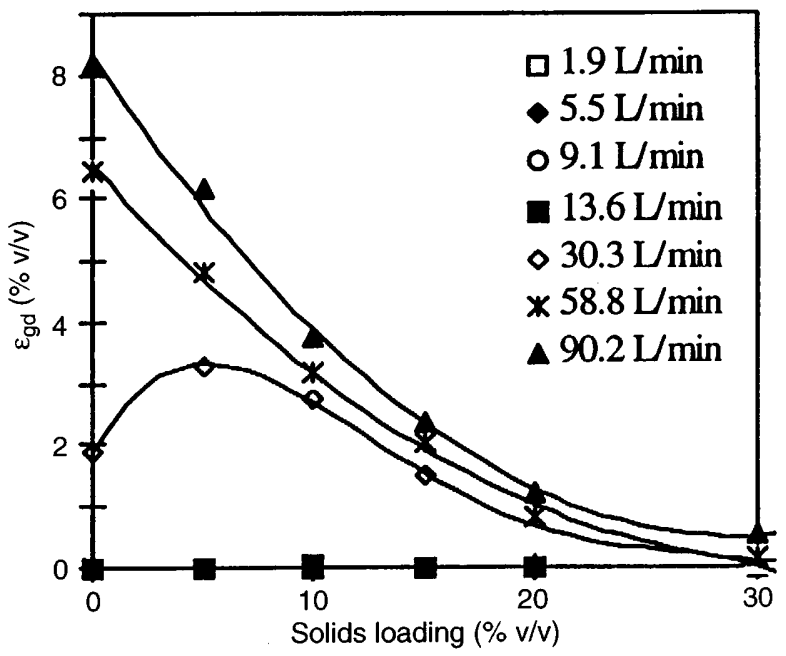

271
Figure 5 indicates that riser and downcomer gas holdup decreases with the increase of solids loading. The addition of solids reduces the flow area of gas and liquid phases. Consequently, bubble coalescence increases and the gas holdup decreases. Bubble coalescence depends also on the diameter of solid particles. Epstein [19] showed that small particles increase the coalescence due to the enhanced viscosity of the pseudohomogeneous three phase medium. Also Brück and Hamer [20] concluded that solid beads with densities lower than $1050 \mathrm{~kg} / \mathrm{m}^{3}$ and diameter ranging from 0.06 to $4.35 \mathrm{~mm}$ cause a decrease in gas holdup.

It can also be seen in Fig. 5 that, for an airflow rate of $30.3 \mathrm{l} / \mathrm{min}$, the downcomer gas holdup increases when $5 \%$ of solids are placed into the reactor, decreasing with the addition of more solids. This could be explained by the drag of air bubbles by the solids. When solids loading is low, the coalescence is not significant so the drag of the bubbles to the downcomer would lead to an increase of downcomer gas holdup. Increasing solids loading, coal-

Fig. 6. Downcomer gas holdup versus riser gas holdup, for different solids loading and for low and high density beads

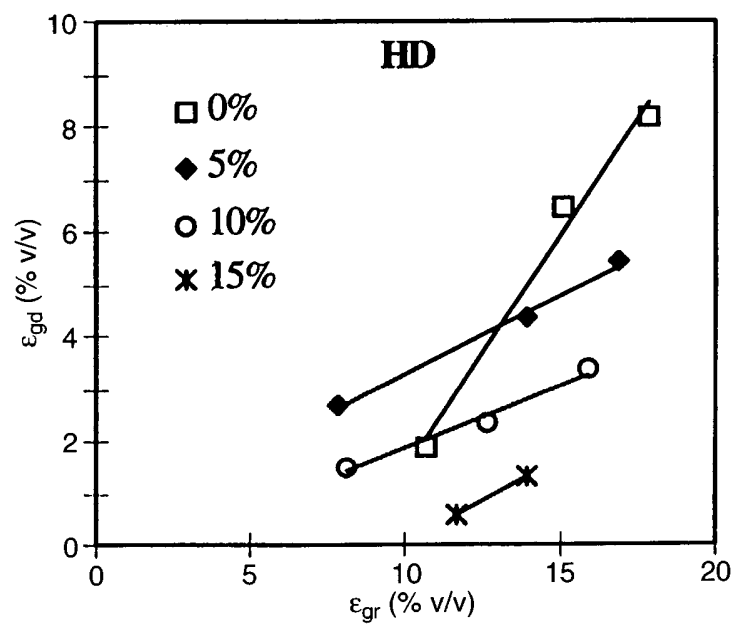


escence increases and overlays the drag of the bubbles. For airflow rates higher than $30.3 \mathrm{l} / \mathrm{min}$, coalescence is very high even for low solids loading and the downcomer gas holdup decreases for all the solids loading studied.

Comparing the decrease of riser gas holdup with solids loading with the decrease of downcomer gas holdup, it is observed that solids loading has a more pronounced effect on downcomer than on riser gas holdup. With air bubbles coalescence occurring in the riser, the rising bubble velocity increases and few bubbles enter the downcomer. Thus, downcomer gas holdup decreases due to bubble coalescence in the downcomer and due to the less amount of air that enters into it.

Figure 6 shows that downcomer gas holdup increases linearly with riser gas holdup, for all solids loading applied. The slope $\left(\varepsilon_{g d} / \varepsilon_{g r}\right)$ is 0.88 for the gas-liquid system as can be seen in Table 1. This value is similar to those found by Bello et al. [21] and by Lu et al. [14] -0.89 and 0.8 , respectively. It can also be seen that the slope decreases with the increase of solids loading, converging to identical values. This is due to the fact that the decrease of
Table 1. Slopes of the linear relationships between downcomer gas holdup and riser gas holdup

\begin{tabular}{lcl}
\hline Solids density & $\begin{array}{l}\text { Solids loading } \\
(\% \mathrm{v} / \mathrm{v})\end{array}$ & $\varepsilon_{g d} / \varepsilon_{g r}$ \\
\hline- & 0 & 0.88 \\
LD & 5 & 0.47 \\
& 10 & 0.16 \\
& 15 & 0.18 \\
& 20 & 0.10 \\
HD & 5 & 0.30 \\
& 10 & 0.24 \\
\hline
\end{tabular}

downcomer gas holdup with solids loading is sharper than the decrease of riser gas holdup (see Fig. 5).

In Figure 7 riser and downcomer gas holdup, obtained for the high and low density beads, are compared, showing a decrease of gas holdup with solids density. This is related with the enhancement of riser and downcomer solids holdup with solids density (see Fig. 2) since the flux area
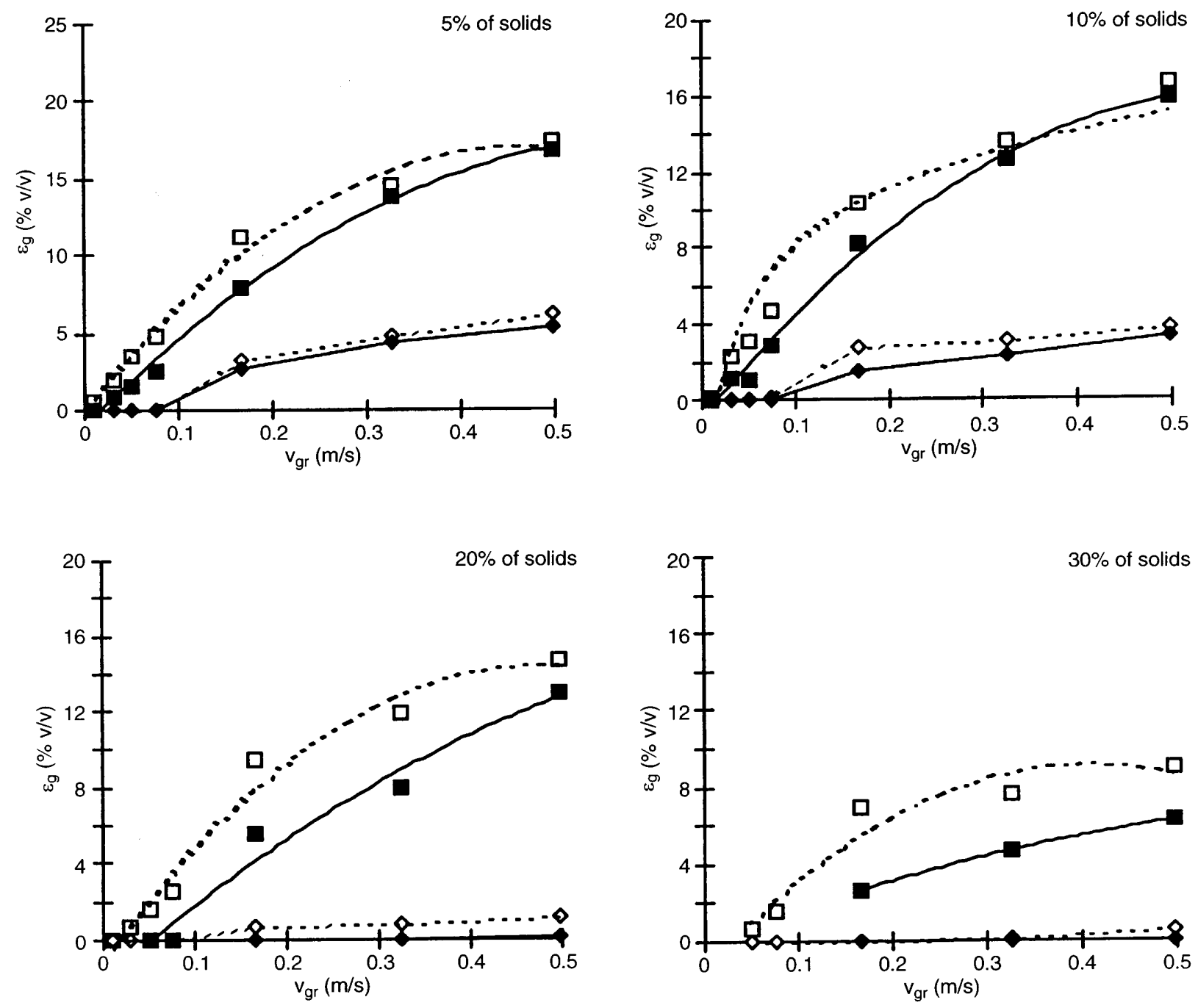

Fig. 7. Influence of solids density on riser and downcomer gas holdup, for different solids loading and riser superficial gas velocity ( $\square$-Ege (LD); $\mathbf{\square}$-Ege (HD); $\diamond$-Egd (LD); $\diamond$-Egd (HD)) 


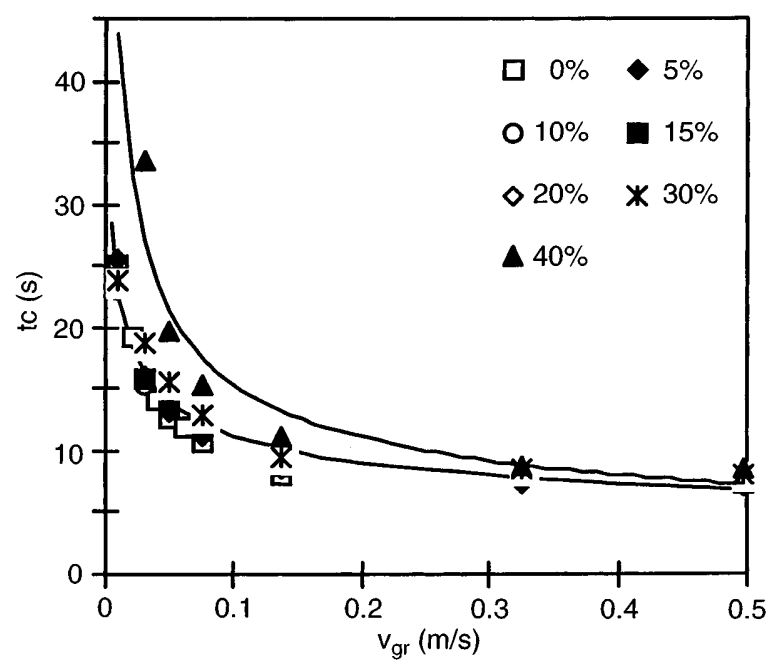

Fig. 8. Circulation time versus riser superficial gas velocity, for different solids loading and for the low density beads

for the gas and liquid phases decreases, increasing coalescence.

Fluid circulation is due to the difference between the fluid density in the riser and in the downcomer, resulting from the injection of air directly into the bottom of riser. This is demonstrated by the fact that the values of riser gas holdup are always higher than those of the downcomer gas holdup. The gap between riser and downcomer gas holdup is widened for high airflow rates resulting in a better fluid circulation.

\section{3}

\section{Circulation time}

The effects of airflow rate on circulation time $\left(t_{c}\right)$ are shown in Figs. 8 and 9, for low and high density beads, respectively. In both cases, circulation time decreases with the increase of airflow rate. In the range of low airflow rates, circulation time is a strong function of the riser superficial gas velocity. After this, it stabilises and its de-

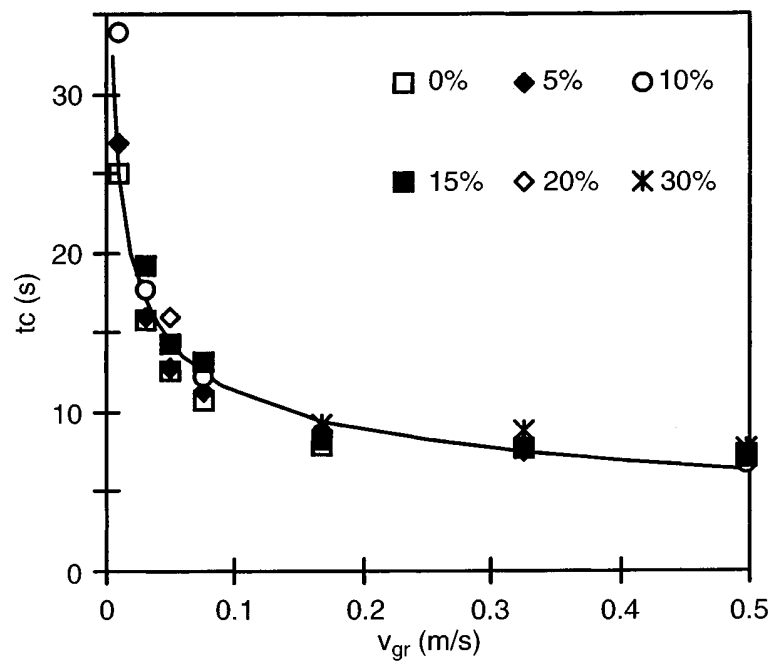

Fig. 9. Circulation time versus riser superficial gas velocity, for different solids loading and for the high density beads

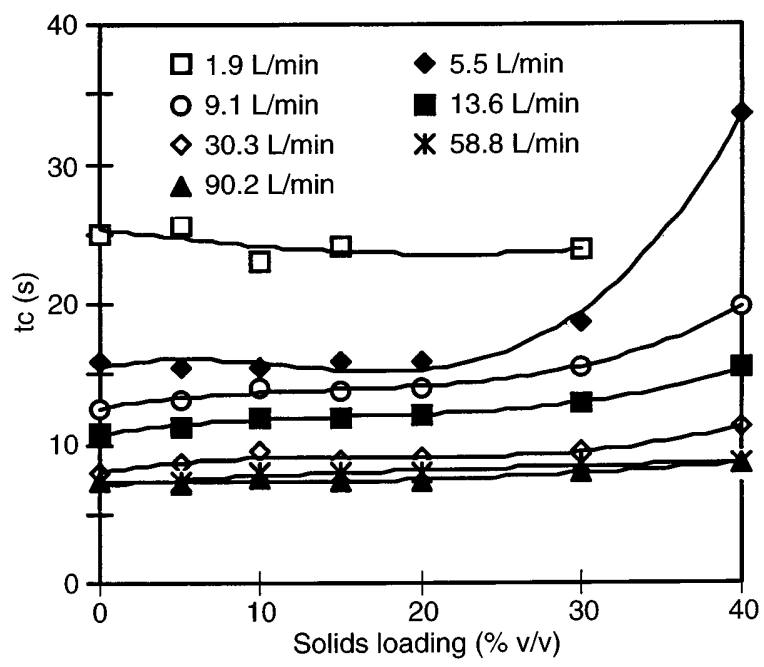

Fig. 10. Circulation time versus solids loading, for different airflow rates and for the low density beads

pendence on airflow rate becomes very weak. This behaviour can be explained by the fact that, for low airflow rates, downcomer gas holdup is zero and that an increase of riser superficial gas velocity leads only to the increase of riser gas holdup. Thus, the difference between riser and downcomer gas holdup, which is in fact the driving force for liquid circulation, becomes larger, liquid velocity increases accordingly and circulation time decreases. At high airflow rates, when riser superficial gas velocity is increased, both riser and downcomer gas holdup increase and its difference presents only a little reduction.

As circulation time is almost constant for solids loading up to $30 \%$ (see Fig. 10), the following correlations between circulation time $\left(t_{c}\right)$ and riser superficial gas velocity $\left(v_{g r}\right)$ were established for that range of solids loading:

For the low density beads:

$t_{c}(\mathrm{~s})=5.494 v_{\mathrm{gr}}(\mathrm{m} / \mathrm{s})^{-0.311} . \quad(\mathrm{c} . \mathrm{c}=0.98)$

For the high density beads:

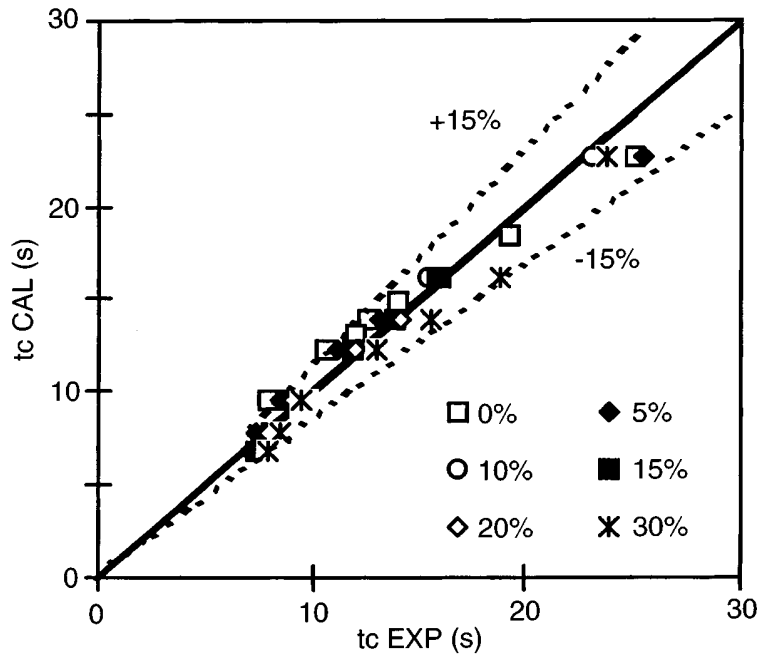

Fig. 11. Circulation time calculated using Eq. (6) versus circulation time measured, for the low density beads 


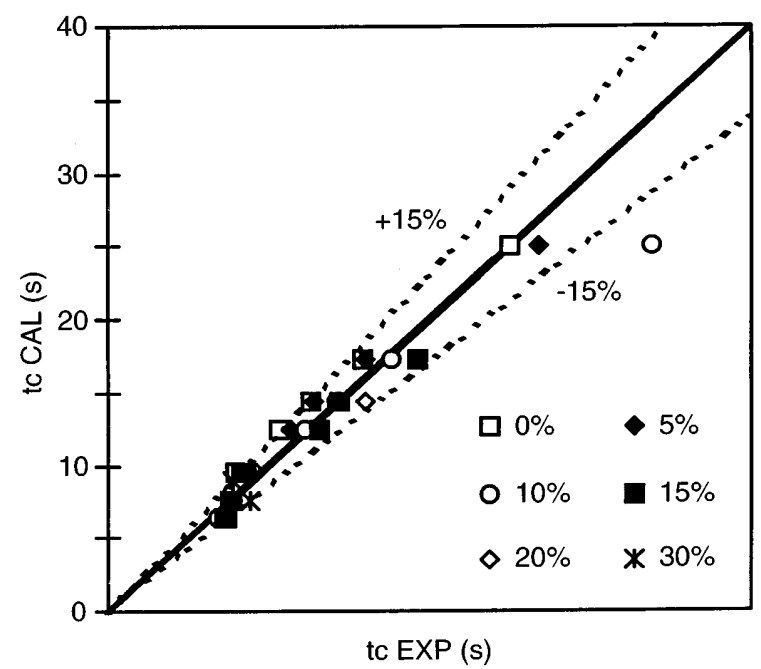

Fig. 12. Circulation time calculated using Eq. (7) versus circulation time measured, for the high density beads
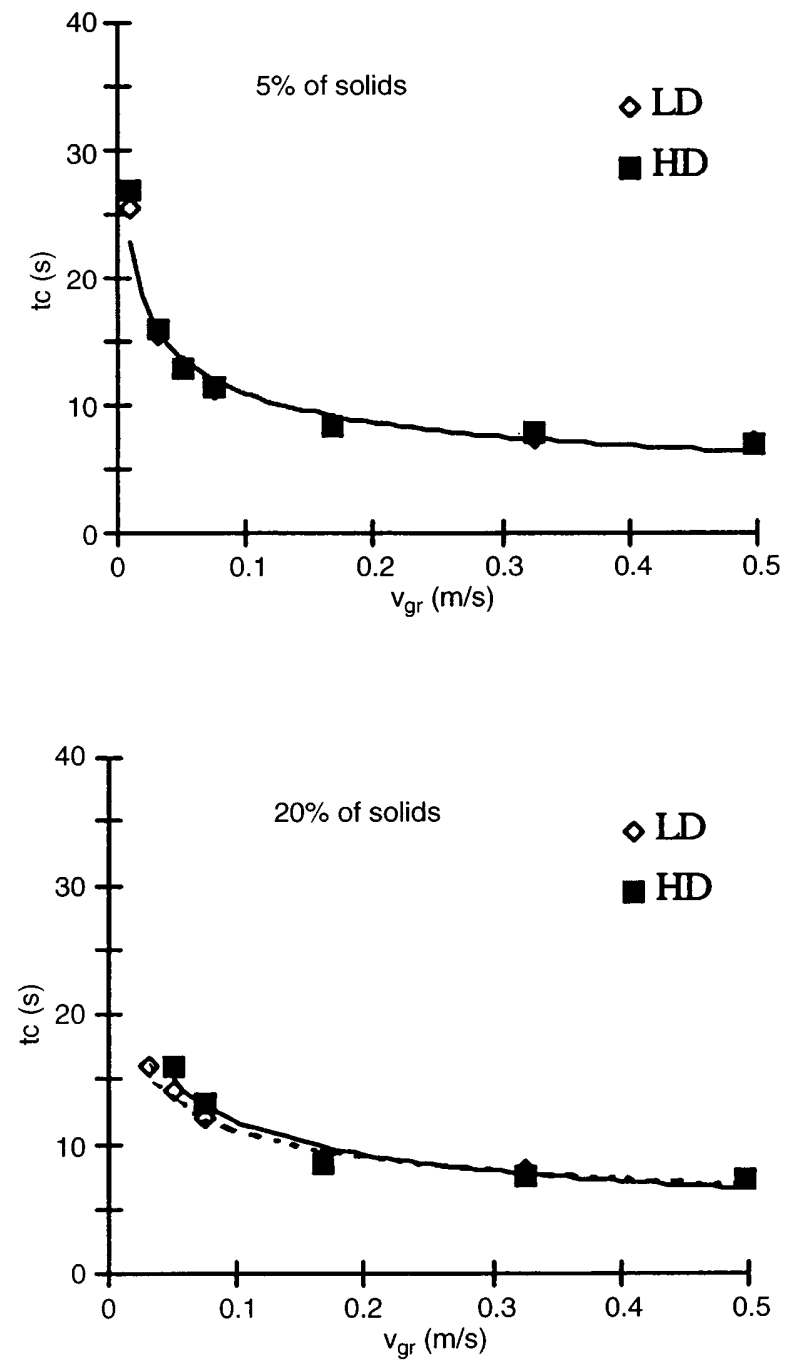

$t_{c}(\mathrm{~s})=5.042 v_{g r}(\mathrm{~m} / \mathrm{s})^{-0.351} . \quad(\mathrm{c} . \mathrm{c}=0.97)$

Bello et al. [22] found a similar equation, for internal and external loop airlift reactors working with a gasaqueous salt solution, where $t_{c} \propto v_{g r}^{-1 / 3}$. The effectiveness of those correlations is shown in Figs. 11 and 12, where the circulation times calculated using Eqs. 6 and 7, respectively, are plotted versus the measured values. An agreement of $\pm 15 \%$ was found.

Figure 13 compares the circulation time for high and low density beads allowing for the conclusion that solids density has a negligible influence on circulation time. Only for low riser superficial gas velocities and, especially, for high solids loading, circulation time increases by increasing solids density. For $30 \%$ of solids, for instance, when with the high density beads there is no circulation for riser superficial gas velocity below $0.17 \mathrm{~m} / \mathrm{s}$, with low density beads the fluid circulates for all the airflow rates studied. This behaviour may be due to similar increase of solids and gas holdup with solids density in the riser and in the downcomer. Thus, the difference between riser and downcomer fluid densities is not very affected, meaning
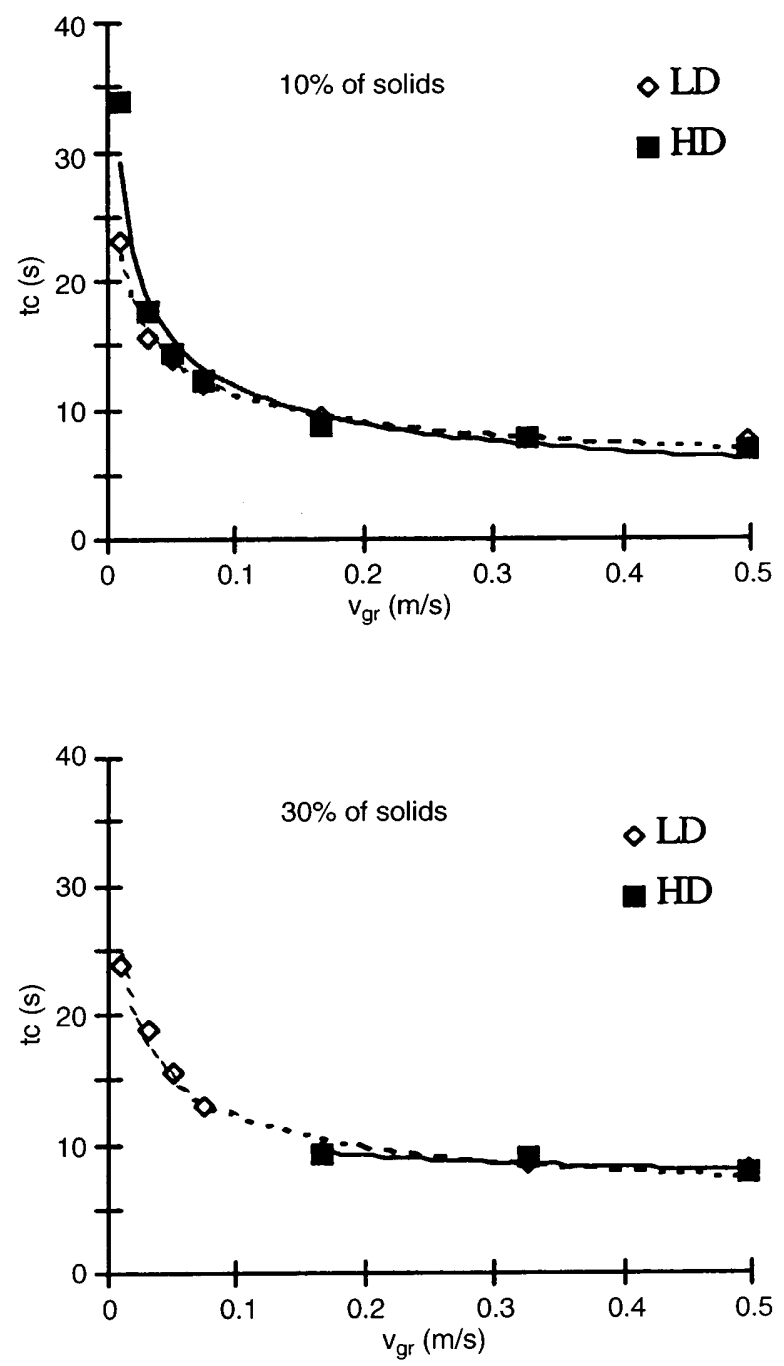

Fig. 13. Influence of solids density on circulation time, for different solids loading and riser superficial gas velocity 

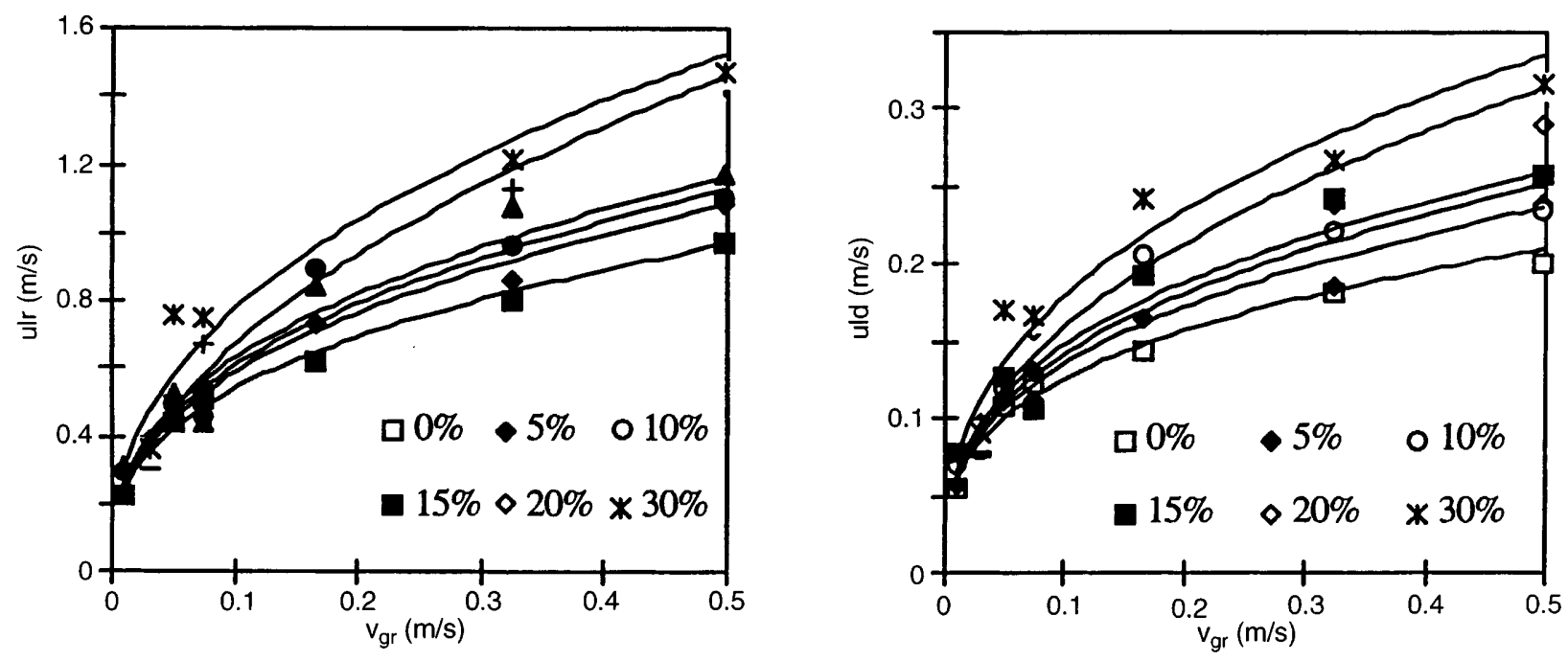

Fig. 14. Riser and downcomer interstitial liquid velocity versus riser superficial gas velocity, for different solids loading and for the low density beads

Table 2. Values of the coefficient $b$ of Eq. (8) for each solids loading and density

\begin{tabular}{llllllll}
\hline & $b$ & & & & & & \\
\cline { 2 - 7 } & Solids loading & $0 \%$ & $5 \%$ & $10 \%$ & $15 \%$ & $20 \%$ & $30 \%$ \\
\hline \multirow{2}{*}{ Riser } & LD & 0.364 & 0.382 & 0.384 & 0.384 & 0.484 & 0.422 \\
\multirow{2}{*}{ Downcomer } & HD & 0.364 & 0.447 & 0.416 & 0.451 & - & - \\
& LD & 0.320 & 0.347 & 0.356 & 0.351 & 0.388 & 0.422 \\
& HD & 0.320 & 0.352 & 0.412 & 0.420 & - & - \\
\hline
\end{tabular}

that the circulation driving force is almost constant. However, for low airflow rates and for high solids loading, the high density beads accumulate at the bottom of the reactor, preventing the entrance of air and making the circulation more difficult and, in some cases, impossible.
3.4

\section{Liquid velocity}

Interstitial liquid velocity in riser $\left(u_{l r}\right)$ and in downcomer $\left(u_{l d}\right)$ increases with airflow rate, for all solids loading and densities studied, as it is illustrated in Fig. 14. There is an initial range of riser superficial gas velocity in which the interstitial liquid velocity is very sensitive to the increase
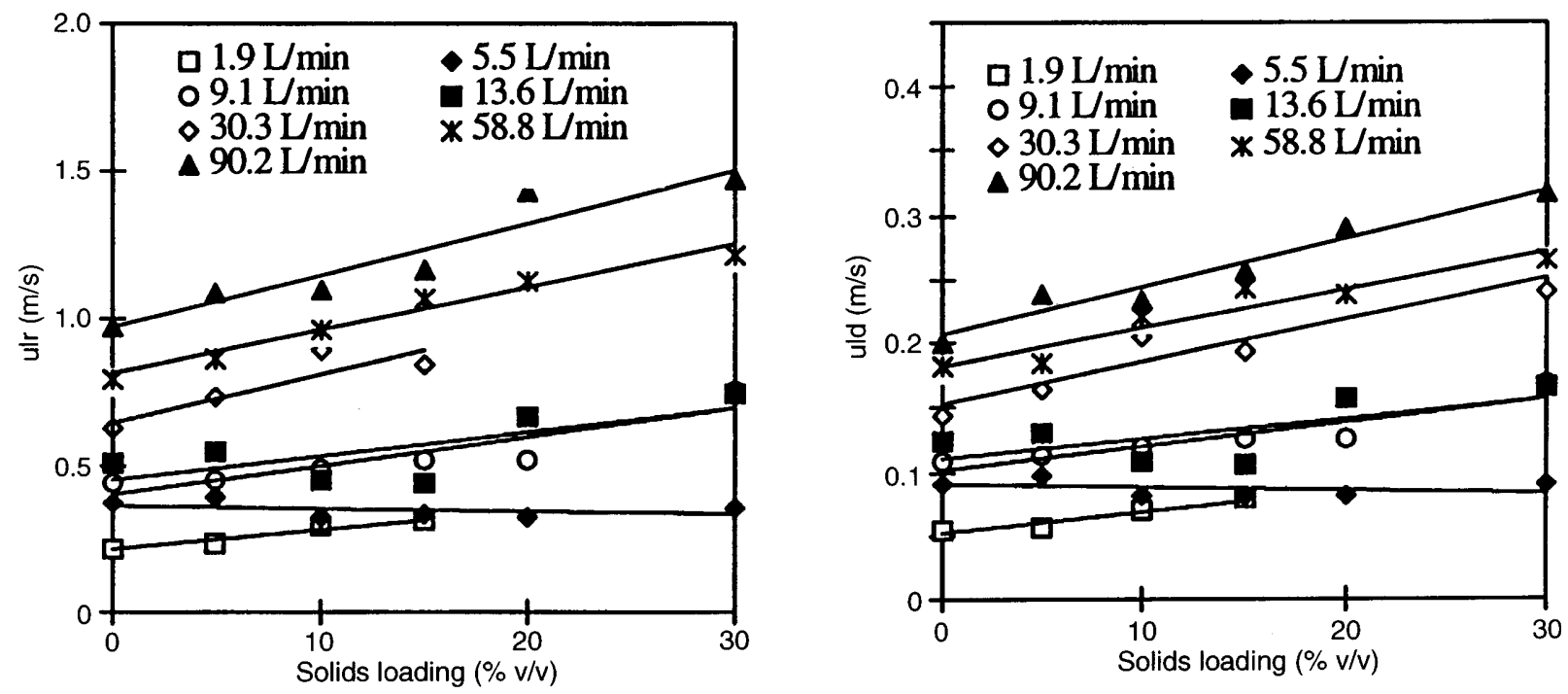

Fig. 15. Riser and downcomer interstitial liquid velocities versus solids loading, for different airflow rates and for the low density beads 

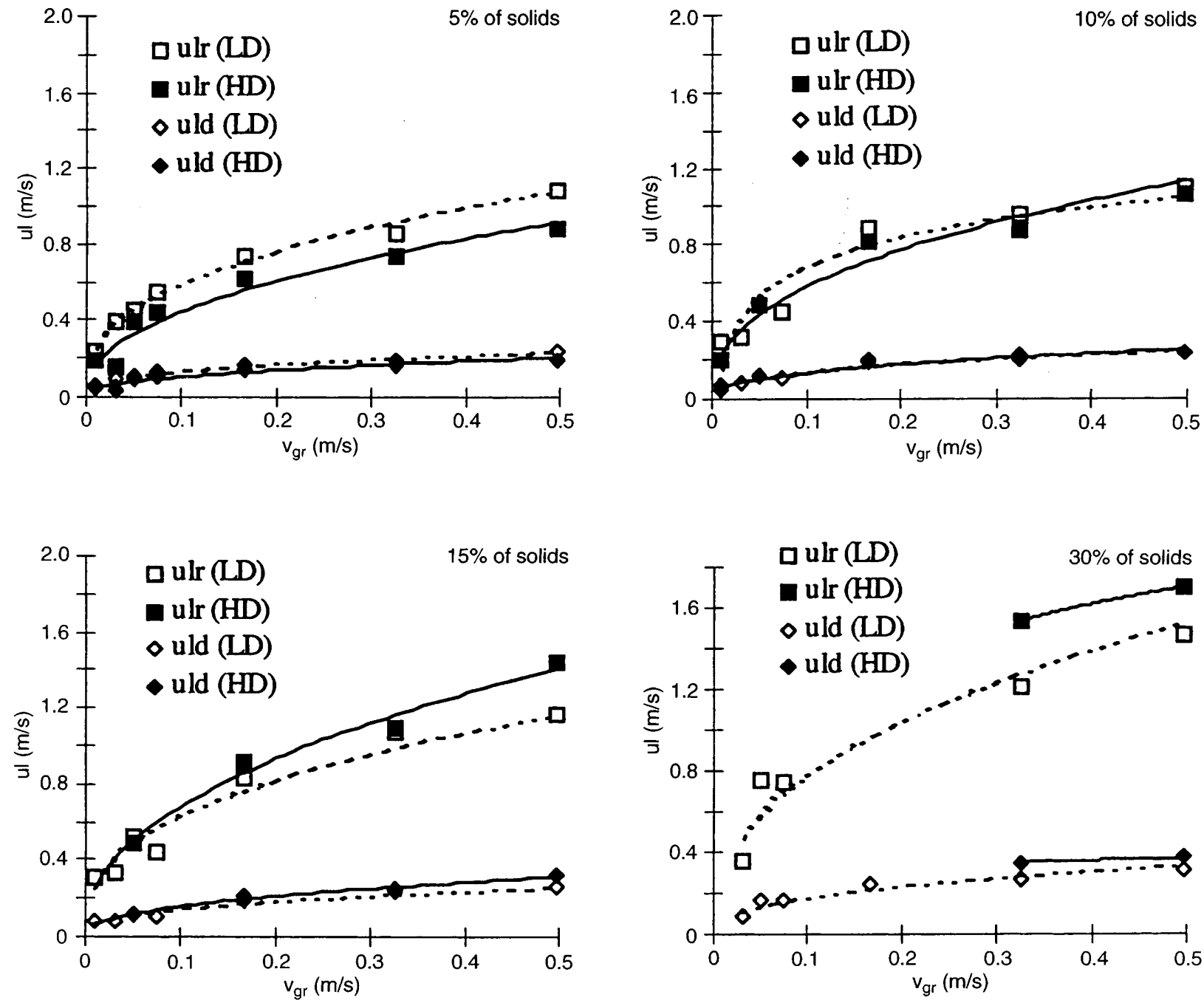

Fig. 16. Influence of solids density on riser and downcomer interstitial liquid velocities, for different solids loading and riser superficial gas velocity

of the airflow rate and, then, a range in which a smaller increase of interstitial liquid velocity with the airflow rate is observed. This variation is related, essentially, with the difference between riser and downcomer gas holdup (see Fig. 7) which leads to the difference in hydrostatic pressure, responsible by the fluid flux. The difference between riser and downcomer solids holdup might influence the liquid velocity but, as shown in Fig. 2, this difference remains approximately zero through the range of airflow rates studied.

The interstitial liquid velocity in riser and in downcomer was correlated to the riser superficial gas velocity, for each solids loading and density, in the form:

$u_{l}=a v_{g r}^{b}$,

where $a$ and $b$ are constants for each experiment. This equation is of the same type of those found by Russel et al. [23] $-u_{l r} \propto v_{g r}^{0.44}-$ during fermentations of Saccharomyces cerevisiae in an airlift reactor of the concentric tube type and by Bello et al. [22] $-u_{l r} \propto v_{g_{r}}^{1 / 3}-$ for internal and

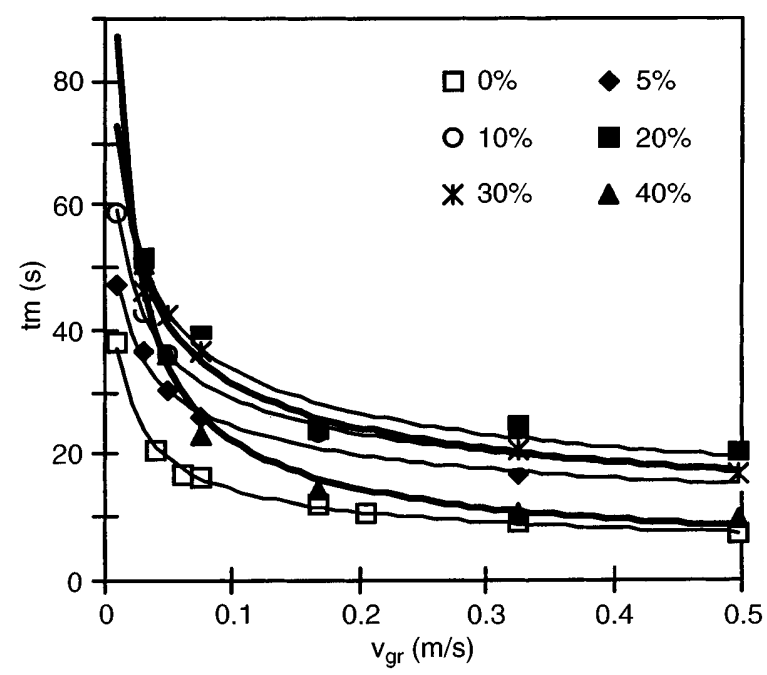

Fig. 17. Mixing time versus riser superficial gas velocity, for different solids loading and for the low density beads 


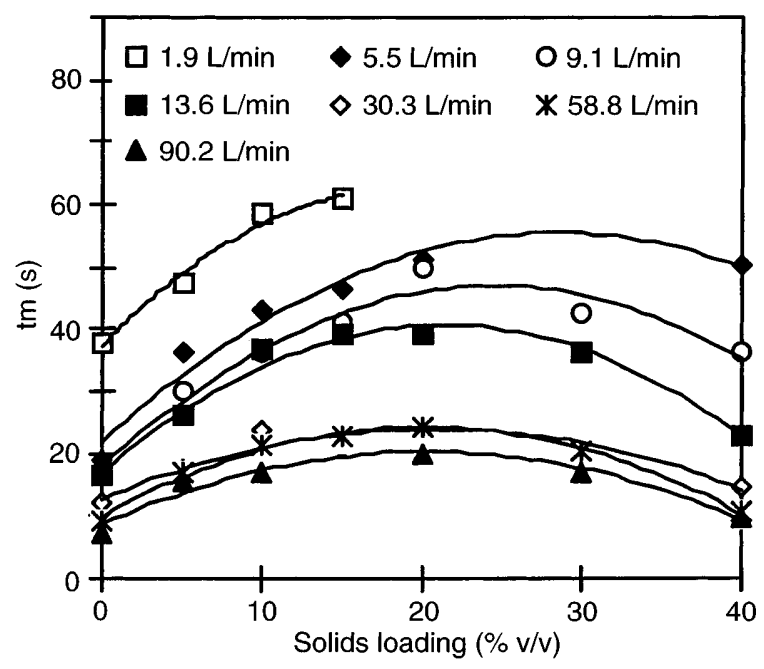

Fig. 18. Mixing time versus solids loading, for different airflow rates and for the low density beads
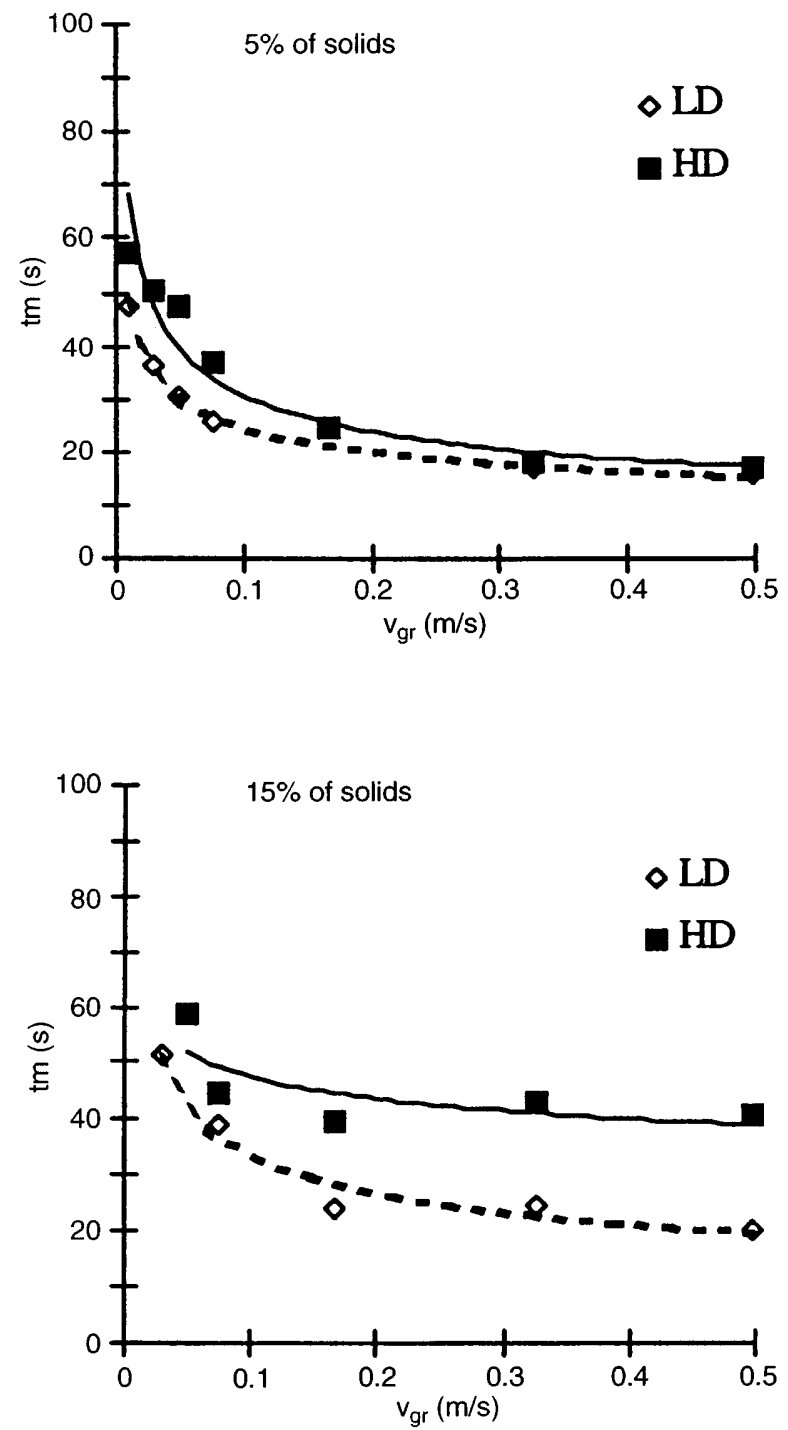

external loop airlift reactors in a gas-aqueous salt solution. Values of $b$ found for the riser interstitial liquid velocity (Table 2) are similar to the values presented by these authors. For $0 \%$ of solids, the exponent of 0.364 is only slightly higher than the $1 / 3$ value of the equation of Bello et al. It was also observed that $b$ generally increases with solids loading and with solids density (Table 2), which may be related with the different changes in gas holdup with airflow rate occurring for each set of experimental conditions. It also presents lower values for the downcomer than for the riser.

Figure 15 illustrates an ascending trend of riser and downcomer interstitial liquid velocities with the increase of solids loading. As solids holdup increases with the increase of solids loading both in the riser and in the downcomer (see Fig. 3), the free area for the fluid flux decreases leading to the enhancement of riser and downcomer interstitial liquid velocity.

In Fig. 16, riser and downcomer interstitial liquid velocities are compared for some of the sets of experimental
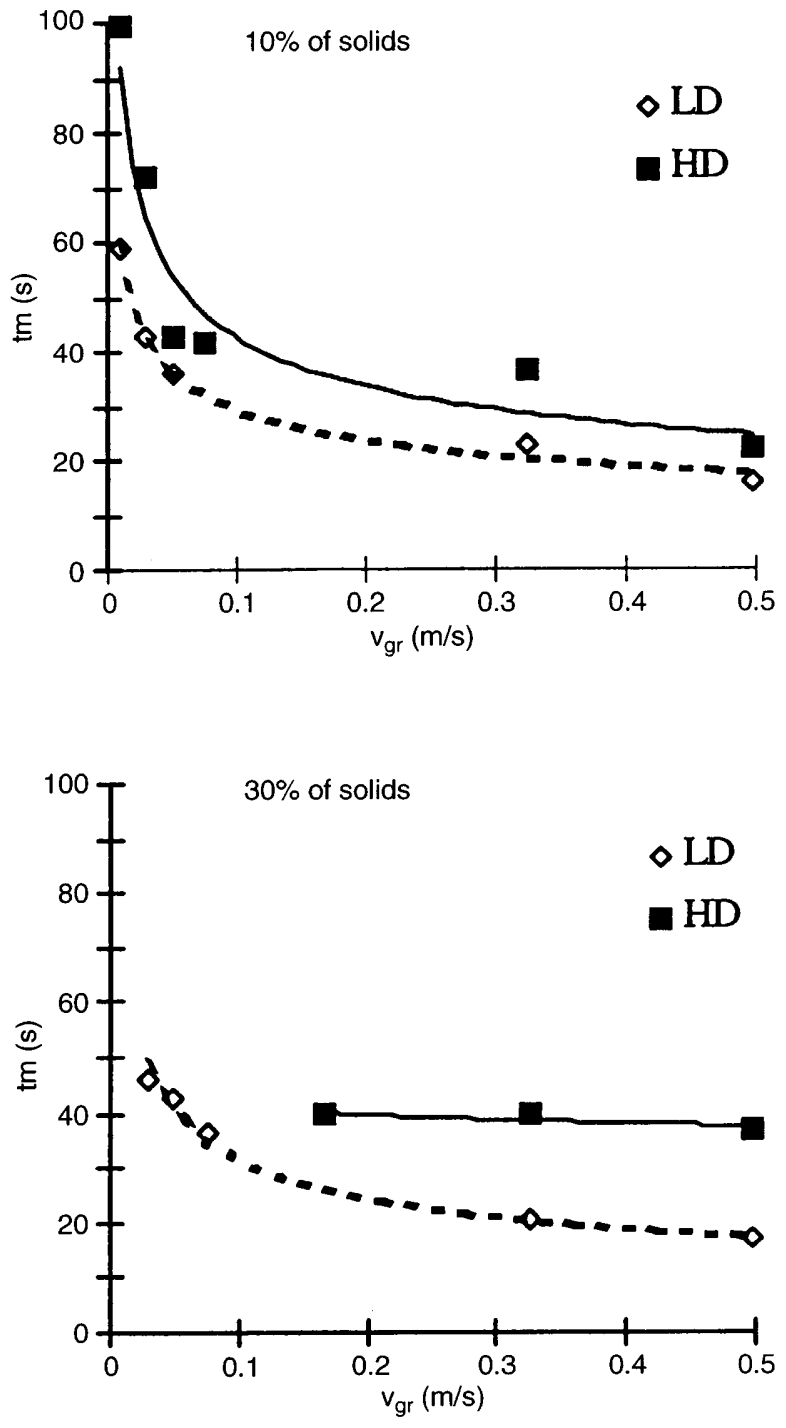

Fig. 19. Influence of solids density on mixing time, for different solids loading and riser superficial gas velocity 
conditions showing that riser interstitial liquid velocity is higher than the downcomer interstitial liquid velocity. The gap between these two velocities widens slightly as the airflow rate increases. Furthermore, it can also be seen in Fig. 16 that riser and downcomer interstitial liquid velocities increase with solids density, for solids loading above $10 \%$. An explanation might be the increase of riser and downcomer solids holdup with solids density. For $5 \%$ of solids, their density almost does not influence solids holdup, either in the riser or in the downcomer (see Fig. 2), but its increase leads to a decrease of riser and downcomer gas holdup (see Fig. 7), increasing the flux area for the liquid phase. A solids loading of $10 \%$ seems to be a transition point for which the increase of solids holdup with solids loading is similar to the decrease of gas holdup.

\section{5}

\section{Mixing time}

Mixing time decreases with airflow rate, as illustrated in Fig. 17. This is observed for all solids loading and for both solids densities studied. In general, mixing time was found to decrease rapidly with the increase of riser superficial gas velocity up to about $0.1-0.2 \mathrm{~m} / \mathrm{s}$, after which mixing time is almost constant. For low airflow rates, an increase in riser superficial gas velocity leads to a significant improvement of the liquid circulation (see Figs. 8 and 9). Liquid moves more often to the degassing zone where most of the mixing takes place, due to the ring vortices formed above the draught tube. For high airflow rates, there is no significant improvement on circulation with the increase of riser superficial gas velocity.

The relation between mixing time and riser superficial gas velocity, for each solids loading and density, can be approximated to:

$t_{m}=a v_{g r}^{b}$,

with $a$ and $b$ changing with the experimental conditions studied. For a gas-liquid system, $b$ is equal to -0.417 which is in agreement with other studies (Kennard and Janekeh [12]; Weiland and Onken [24]).

Figure 18 shows that mixing time increases with solids loading attaining a maximum, for approximately $20 \%$ of solids, after which it decreases. This can be explained by the fact that, for solids loading up to $20 \%$, the enhancement of solids loading leads to a decrease of the free area for fluid flux and, as a consequence, the fluid contact is much difficult and mixing becomes worse. For higher solids loading, the collisions between solids increase with the increase of solids loading and there are probably more vortices that will improve mixing.

For an airflow rate of $1.9 \mathrm{l} / \mathrm{min}$, no circulation is observed for solids loading higher than $15 \%$.

The influence of solids density on mixing time is presented in Fig. 19. It shows that mixing becomes slower with the increase of solids density. As riser and downcomer solids holdup increase with solids density (see Fig. 2), the high density beads do not rise as much to the degassing zone as the low density ones. Since it is at the degassing zone that most of the mixing takes place, a decrease in density causes a slower mixing.

\section{4}

\section{Conclusions}

The hydrodynamic behaviour of a 601 three-phase airlift bioreactor of the concentric draught tube type, with an enlarged degassing zone, was studied. The effects of airflow rate, solids loading and density on gas and solids holdup in the riser and in the downcomer, circulation and mixing times and interstitial liquid velocity were investigated.

It was found that riser and downcomer solids holdup decrease slightly with the increase of airflow rate, for the lower values of this variable. For the higher values of airflow rate, solids holdup is practically constant. The increase of solids loading and density causes an increase of riser and downcomer solids holdup.

Riser and downcomer gas holdup increase with airflow rate and decrease with solids loading and density. Downcomer gas holdup is null for airflow rates up to $13.6 \mathrm{l} / \mathrm{min}$.

Circulation and mixing times decrease with the increase of airflow rate, mainly for airflow rates below $30.3 \mathrm{l} / \mathrm{min}$. For higher airflow rates, there is no significant improvement on circulation and mixing times with the increase of airflow rate.

Circulation time is little influenced by solids loading and density. It only increases with solids loading for low airflow rates and for high solids loading and it only increases with solids density for low airflow rates. On the contrary, mixing time is strongly affected by these variables, showing a maximum for solids loading of approximately $20 \%(\mathrm{v} / \mathrm{v})$. When solids density is increased, mixing time increases, being the increase more relevant for high solids loading.

The interstitial liquid velocity in the riser and in the downcomer increases with airflow rate, with solids loading and, in general, with solids density.

\section{References}

1. Chisti, Y.; Moo-Young, M.: Improve the performance of airlift reactors. Chem. Eng. Progress June (1993) 38-45

2. Merchuk, J.C.; Ladwa, N.; Cameron, A.; Bulmer, M.; Pickett, A.: Concentric-tube airlift reactors: Effects of geometrical design on performance. AIChE J. 40 (1994) 1105-1117

3. Moresi, M.: Optimal design of airlift fermenters. Biotechnol. Bioeng. XXIII (1981) 2537-2560

4. Thomas, N.H.; Janes, D.A.: Fluid dynamic considerations in airlift bioreactors. Biotechnol. Processes, 60-71

5. Siegel, M.; Merchuk, J.C.: Hydrodynamics in rectangular airlift reactors, scale-up and the influence of gas-liquid separator design. The Can. J. Chem. Eng. 69 (1991) 465-473

6. Siegel, M.H.; Merchuk, J.C.; Schugerl, K.: Air-lift reactor analysis: Interrelationships between riser, downcomer, and gas-liquid separator behaviour, including gas recirculation effects. AIChE J. 32 (1986) 1585-1596

7. Vicente, A.A.; Teixeira, J.A.: Hydrodynamic performance of a three-phase airlift bioreactor with an enlarged degassing zone. Bioprocess Eng. 14 (1995) 17-22

8. Assa, A.; Bar, R.: Biomass axial distribution in airlift bioreactor with yeast and plant cells. Biotechnol. Bioeng. 38 (1991) $1325-1330$

9. Fan, L.-S.; Hwang, S.-J.; Matsuura, A.: Hydrodynamic Behaviour of a draft tube gas-liquid-solid spouted bed. Chem. Eng. Science 39 (1984) 1677-1688

10. Ijichi, K.; Tanaka, Y.; Uemura, Y.; Hatate, Y.; Yoshida, K.: Solids-circulation rate and holdup in the draft tube of a spouted bed. International Chem. Eng. 34 (1994) 370-376 
11. Kawase, Y.; Hashimoto, N.: Gas hold-up and oxygen transfer in three-phase external-loop airlift bioreactors, non-newtonian fermentation broths. J. Chem. Tech. Biotechnol. 65 (1996) 325-334

12. Kennard, M.; Janekeh, M.: Two- and three-phase mixing in a concentric draft tube gas-lift fermentor. Biotechnol. Bioeng. 38 (1991) 1261-1270

13. Livingston, A.G.; Zhang, S.F.: Hydrodynamic behaviour of three-phase (gas-liquid-solid) airlift reactors. Chem. Eng. Science 48 (1993) 1641-1654

14. Lu, W.-J.; Hwang, S.-J.; Chang, C.-M.: Liquid velocity and gas holdup in three-phase internal loop airlift reactors with lowdensity particles. Chem. Eng. Science 50 (1995) 1301-1310

15. Siegel, M.H.; Hallaile, M.; Herskowitz, M.; Merchuk, J.C.: Hydrodynamics and mass transfer in a three-phase air-lift reactor In: King, R. (Ed.), 2nd International Conference on Bioreactor Fluid Dynamics, 21-23 of September 1988, pp. 337-353

16. Smith, B.S.; Skidmore, D.R.: Mass transfer phenomena in an airlift reactor, effects of solids loading and temperature. Biotechnol. Bioeng. 35 (1990) 483-491

17. Verlaan, P.; Tramper, J.: Hydrodynamics, axial dispersion and gas-liquid oxygen transfer in an airlift-loop bioreactor with three-phase flow. International Conference on Bioreactors and Biotransformations, paper I4 (1987) 363-373

18. Verlaan, P.; Tramper, J.; van't Riet, K.: A hydrodynamic model for an airlift-loop bioreactor with external loop. The Chem. Eng. J. 33 (1986) B43-B53

19. Epstein, N.: Three phase fluidisation: some knowledge gaps. Canadian J. of Chem. Eng. 59 (1981) 649-657

20. Brück, F.J.; Hammer, H.: Intensiviering des stoffanstansches in blasensaüken-reaktoren durch suspen-dierten feststoffen. Chem. -Ing. -techn. 58 (1986) 60-61

21. Bello, R.A.; Robinson, C.W.; Moo-Young, M.: Gas holdup and overall volumetric oxygen transfer coefficient in airlift contactors. Biotechnol. Bioeng. 27 (1985) 369-381

22. Bello, R.A.; Robinson, C.W.; Moo-Young, M.: Liquid circulation and mixing characteristics of airlift contactors. Can. J. Chem. Eng. 62 (1984) 573-577

23. Russel, A.B.; Thomas, C.R.; Lilly, M.D.: The influence of vessel height and top-section size on the hydrodynamic characteristics of airlift fermenters. Biotechnol. Bioeng. 43 (1994) 69-76

24. Weiland, P.; Onken, U.: Differences in the behaviour of bubble columns and airlift loop reactors. Ger. Chem. Eng. 4 (1981) 174-181 